Biochem. Lett, Vol. 6, PP. $23-43$ (2010)

\title{
IMMUNOTOXIC ACTION OF POSTORAL ADMINISTRATION OF CARBON TETRACHLORIDE IN MALE ALBINO RAT
}

\author{
Nagi A. Ibrahim, Al Ahmady S. Alzahaby, \\ Amr A. Shalaby, Eman S. El-Bahaie \\ Zoology Department, Faculty of Science, Zagazig University
}

\begin{abstract}
Carbon tetrachloride (CCl4) was administered (p.o.) every other day for one month to male Sprague Dawely rats. At the first day after the treatment period, leucocytes (WBCs), and lymphocytes (LYM) numbers, and serum IgM level were significantly higher than those of the control values. At day 15 after CCl4 treatment period WBCs and LYM numbers were below the control levels, whereas, IgM was still above the control level, but lower than the value recorded at day one after CCl4 treatment period. The same dose level and treatment period of $\mathrm{CCl} 4$ induced significant increases in serum IL-4 and IL-6 levels that were lasted for 15 days post the administration period. Late administration (i.p.) of DMSO (0.5 $\mathrm{ml} / 100 \mathrm{~g}$ b.wt.) at 30 minutes post CCl4 treatment period selectively prevented changes of WBCs and LYM.Tthese results indicate that the toxic effect of CCl4 under the present experimental conditions, could induce changes in both cellular and humoral immune response of rats and these changes could be selectively reversed with time and late administration of DMSO.
\end{abstract}




\section{INTRODUCTION}

Carbon tetrachloride $\left(\mathrm{CCl}_{4}\right)$ is a clear, colourless, heavy, and non-flammable liquid (1). The average daily intake of $\mathrm{CCl}_{4}$ for the general population is estimated to be $0.1 \mu \mathrm{g}$. Once exposed to this toxic compound by ingestion, inhalation or skin absorption, it is distribution throughout the body, with highest concentrations in the liver, brain, kidney, muscle, fat and blood ${ }^{(1)}$. In spite of the its obvious deleterious effects, $\mathrm{CCl}_{4}$ is still used as a solvent for oils, fats, lacquers, varnishes rubber waxes and resins ${ }^{(2,1)} \cdot \mathrm{CCl}_{4}$ is a well known hepatotoxin and nephrotoxin ${ }^{(3,4,5)}$. It has also been identified as a probable human carcinogen based on evidence of tumors in animals (16). Furthermore, $\mathrm{CCl}_{4}$ has been demonstrated as a potent immunosuppressive agent $\mathbf{( 7 , 8 , 9 , 1 0 , 1 1 )}$. Several agents have been reported to reduce or erase the toxic effect of $\mathrm{CCl}_{4}$, these include propolis extract ${ }^{(\mathbf{1 2})}$, ginkobiloba extract ${ }^{(\mathbf{1 3}, 14,15)}$, black tea extract ${ }^{(\mathbf{1 5})}$, and caffeic acid phenthyl ester ${ }^{(4)}$.

The immunoglobulins are proteins with anti-body activity; i.e., they combine specifically with the substance that elicite their formation (immunogen or antigen), and they make up the humoral arm of the immune response. With the possible exception of "natural" antibody, antibodies arise in response to foreign substances introduced into the body. They are therefore products of induced responses. The immunoglobulins, which circulate in body fluids, comprise a heterogeneous family of proteins, they account for approximately $20 \%$ of the total plasma proteins (Goodman, 1991).

The two hallmarks of immunoglobulins are the specificity of each for one particular antigenic structure and their diversity as a group, which meets the challenge of a vast array of antigenic structures in the environment. In addition to specifically binding antigens, the immunoglobulins express secondary biologic activities, which are important in defense against disease, e.g., transplacental passage, and facilitation of phagocytosis (Goodman, 1991).

IgM is secreted by plasma cells (Goldsby et al., 2003). It constitutes approximately $10 \%$ of normal immunoglobulins and normally exists as a pentamer with a molecular weight of approximately 900,000(19S) (Goodman, 1991) 
IgM antibody is prominent in early immune responses to most antigens and predominates in certain antibody responses such as "natural" blood group antibodies. IgM is the major immunoglobulin expressed on the surface of B cells (Goodman, 1991).

Cytokines are soluble proteins that affect an array of biological processes including inflammation and immunity. Almost every mammalian cell type has the capability to produce and respond to cytokines (Dinarello, 2007).

Interleukin-4 (IL-4) is a cytokine with multiple activities that is mainly produced by the helper CD4 T-lymphocytes of the TH2 subset. It is both an early and late acting growth and differentiation factor for B-lymphocytes which increases cell surface expression of both class II histocompatibility antigens (Noelle et al., 1984; Roehm et al., 1984) and the low affinity receptor for IgE (DeFrance et al., 1987).

Interleukin-6 (IL-6) is a poleiotropic cytokine with both pro and anti-inflammatory properties (Barton, 1996). This cytokine is expressed by a variety of cells, including lymphocytes, monocytes, macrophages, neutrophils, endothelial cells, epithelial cells, and fibroblasts (Biffl et al., 1996; van der Boll and van Deventer, 1998).

Dimethyl sulfoxide (DMSO), an amphipathic solvent soluble in both aqueous and organic media if often used to dissolve hydrophobic substances employed in biological research (Basile et al., 1996; Szonyi et al. 2001; Harris et al., 2005). In experimental studies, DMSO has been shown to effectively prevent the chemicallyinduced liver or kidney damage (Lind \& Grandolfi, 1997, 1999; Gilot et al., 2002; Kishioka et al., 2007). The objective of this study was to further delineate the effects of $\mathrm{CCl}_{4}$ on the immune system in male albino rats and the possible protective action of late administration of DMSO against these effects.

\section{MATERIAL AND METHODS}

Male Sprague-Dawely rats weiging 150-200 g were used in this study. They were obtained from the animal house of the National Research Center, doki, Giza. Rats were housed under standard laboratory conditions. They had free access to a standard food and 
provided with tap water ad libitum. All animals were acclimatized to these conditions for 10 days before being used.

Carbon tetrachloride and dimethyl sulfoxide were applied in the present study as commercial solutions. $\mathrm{CCl}_{4}$ was obtained from Merck (Germany) DMSO City, Egypt was obtained from NOURESH'SHARK Co. $10^{\text {th }}$ of Ramadan

The acute post oral $\mathrm{LD}_{50}$ of $\mathrm{CCl}_{4}$ for male Sprague-Dawely rats was determined according to the method of Reed and Meuench (32) and was found to be $0.9 \mathrm{ml} / 100 \mathrm{~g} \mathrm{~b} . w \mathrm{t} .,(1.431 \mathrm{~g} / 100 \mathrm{~g}$ b.wt.).

Animals were randomly allocated into 3 groups (10 rats in each group).

Rats of group 1: were not treated and used as controls.

Rats of group 2: received postorally $\mathrm{CCl}_{4}$ at the dose level of 1/10

$\mathrm{LD}_{50} / 100 \mathrm{~g}$ b.wt. every other day for one month.

Rats of group 3: were injected subcutaneously with DMSO at the dose level of $0.05 \mathrm{ml} / 100 \mathrm{~g}$ b.wt 30 minutes after each $\mathrm{CCl} 4$ treatment, the desired dose of DMSO was diluted by distilled water to a volume of $0.5 \mathrm{ml}$ for each rat.

From each group, 5 rats were deprived of food for overnight before the $1^{\text {st }}$ day and 15 days following termination of each treatment period.

These rats were slightly anaesthetized with ether and blood samples were collected through heart puncture into plain tubes and centrifuged at $3000 \mathrm{rpm}$ for 15 minutes. Serum was separated in eppendorfs and kept at $-80^{\circ} \mathrm{C}$ till the immunological analysis were started. Other blood samples were collected into vaccutainer tubes containing EDTA for haematological analysis.

\section{Determination of serum immunoglobulin IgM:}

IgM in serum samples of control and treated rats were assayed by means of immunonephelometry on the BN ProSpec System manufactured by Dade Behring GnbH, Marburg, Germany. 


\section{Determination of the serum cytokines interleukin-4 (IL-4) and interleukin-6 (IL-6):}

IL-4 and IL-6 concentrations in serum samples of control and treated rats were measured using AviBion Enzyme-Linked Immunosorbent Assay (ELISA) kits (Orgenium Laboratories, Helsinki, Finland), according to the manufacturer's instructions.

\section{Determination of haematological parameters:}

Total white blood cells (WBCs) number and lymphocyte (Lym) number, were measured following the methods described by Brown (33) using the automated haematology analyzer, Sysmex KX$21 \mathrm{~N}$ manufactured by Sysmex Co. Kobe, Japan. Statistical analysis.

\section{RESULTS}

Data presented in table (1) and illustrated graphically in figure (1) indicate that subchronic postoral administration of $\mathrm{CCl}_{4}(0.09$ $\mathrm{ml} / 100$ g. wt.) every other day for one month caused a significant increase in total WBCs and lymphocyte (LYM) numbers above the control at the first day after the end of treatment, and were decreased but not significantly below the control at the day 15 post treatment.

Table (2) and figure (2) demonstrate a significant elevation of serum IgM above the control level after the termination of $\mathrm{CCl}_{4}$ treatment. This elevation was more pronounced at the first day that observed at the fifteenth day of the post treatment period.

Table (3) and figure (3) show that $\mathrm{CCl}_{4}$ treatment induced significant increases in IL-6 that were last significantly for 15 days after $\mathrm{CCl}_{4}$ administration was terminated.

Administration of DMSO $(0.5 \mathrm{ml} / 100 \mathrm{~g}$ b.wt. ip $)$ at 30 minutes after each $\mathrm{CCl}_{4}$ treatment selectively prevented the $\mathrm{CCl}_{4}$-induced changes in WBCs and LYM numbers (Table 1 and Fig. 1), but had no effects on $\mathrm{CCl}_{4}$-induced changes in IgM (table 2 and Fig. 2) and in IL4 and IL-6 as seen in table (3) and figure (3). 
Table (1): The effects of postoral administration of $\mathrm{CCl}_{4}(0.09 \mathrm{ml}$ $/ 100 \mathrm{~g}$ b.wt. $)$ and that of DMSO $(0.05 \mathrm{ml} / 100 \mathrm{~g} \mathrm{b.wt}$. $)$ administered intraperitoneally 30 minutes post each $\mathrm{CCl}_{4}$ administration every other day for one month on total leukocytes (WBCs) and lymphocytes (LYM) numbers in male albino rats at the $1^{\text {st }}$ day and 15 days following termination of treatment period.

\begin{tabular}{|c|c|c|c|c|c|}
\hline $\begin{array}{l}\text {.Measured } \\
\text { parameters }\end{array}$ & Treatment & $\begin{array}{c}\text { Post- } \\
\text { treatment } \\
\text { period }\end{array}$ & Control & Treated & $\begin{array}{c}\% \\
\text { difference }\end{array}$ \\
\hline \multirow{4}{*}{ WBCs $\left(\times 10^{3} / \mu \mathrm{l}\right)$} & \multirow{2}{*}{$\mathrm{CCl}_{4}$} & 1 day & $8.78 \pm 0.6398$ & $14.14 \pm 1.3163^{\mathrm{a}^{+}}$ & 61.05 \\
\hline & & 15 days & $8.28 \pm 0.8108$ & $7.54 \pm 1.1474^{\mathrm{a}-}$ & -8.94 \\
\hline & \multirow{2}{*}{$\begin{array}{c}\mathrm{CCl}_{4} \\
+ \\
\mathrm{DMSO}\end{array}$} & 1 day & $8.78 \pm 0.6398$ & $9.95 \pm 0.4904^{\mathrm{a}-}$ & 13.33 \\
\hline & & 15 days & $8.28 \pm 0.8108$ & $8.08 \pm 0.8772^{\mathrm{a}-}$ & -2.42 \\
\hline \multirow{4}{*}{ LYM (x10 $3 / \mu \mathrm{l})$} & \multirow[t]{2}{*}{$\mathrm{CCl}_{4}$} & 1 day & $6.22 \pm 0.6003$ & $10.12 \pm 0.8963^{\mathrm{a}+}$ & 62.70 \\
\hline & & 15 days & $6.00 \pm 0.6261$ & $5.58 \pm 0.9682^{\mathrm{a}-}$ & -7.00 \\
\hline & \multirow{2}{*}{$\begin{array}{c}\mathrm{CCl}_{4} \\
+ \\
\mathrm{DMSO}\end{array}$} & 1 day & $6.22 \pm 0.6003$ & $7.20 \pm 0.4626^{\mathrm{a}-}$ & 15.76 \\
\hline & & 15 days & $6.00 \pm 0.6261$ & $5.84 \pm 0.4331^{\mathrm{a}-}$ & -2.67 \\
\hline
\end{tabular}

a+: Significant when compared with the control value where $\mathrm{P} \leq 0.05$ (t-test)

a- : Non significant when compared with the control value where $\mathrm{P} \leq 0.05$ (t-test) 


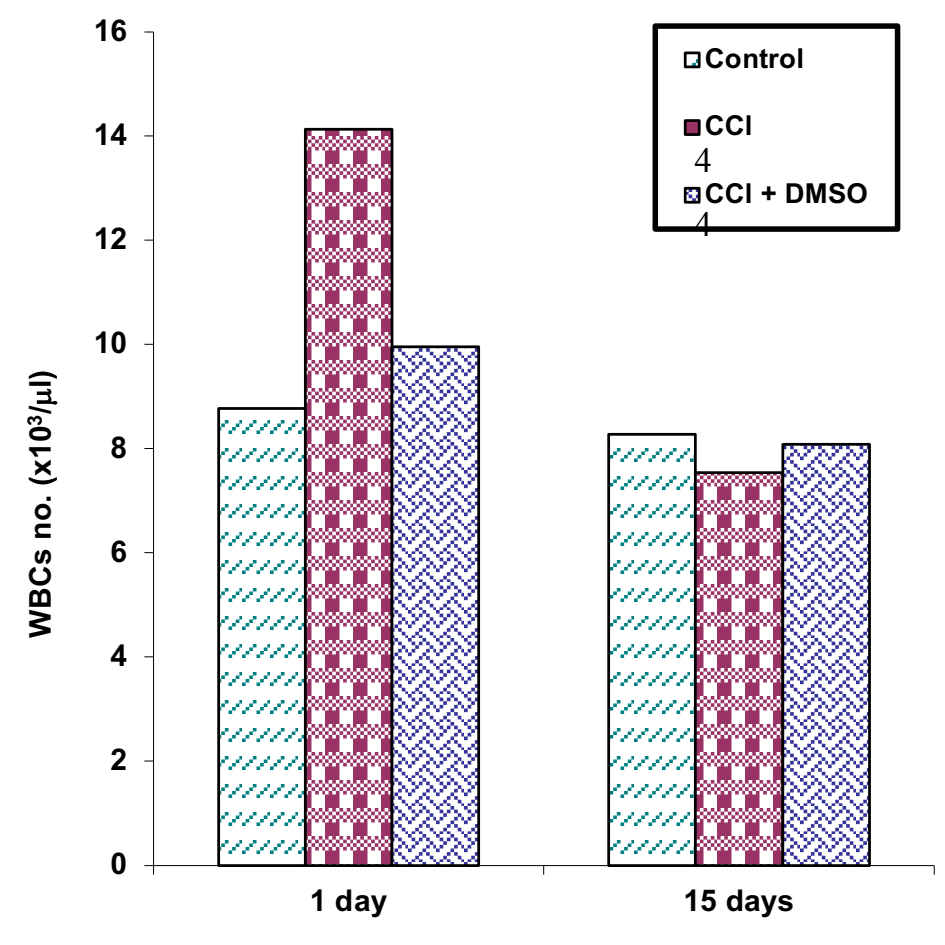

post treatment period

Fig(1): The effects of postoral administration of $\mathrm{CCl}_{4}(0.09 \mathrm{ml} / 100$ g b.wt.) and that of DMSO (0.05 ml /100 g b.wt.) administered intraperitoneally 30 minutes post each $\mathrm{CCl}_{4}$ administration every other day for one month on total leukocytes (WBCs) number in male albino rats at the $1^{\text {st }}$ day and 15 days following termination of treatment period. Each value represents the mean $\pm \mathrm{SE}$ of five separate experiments. 


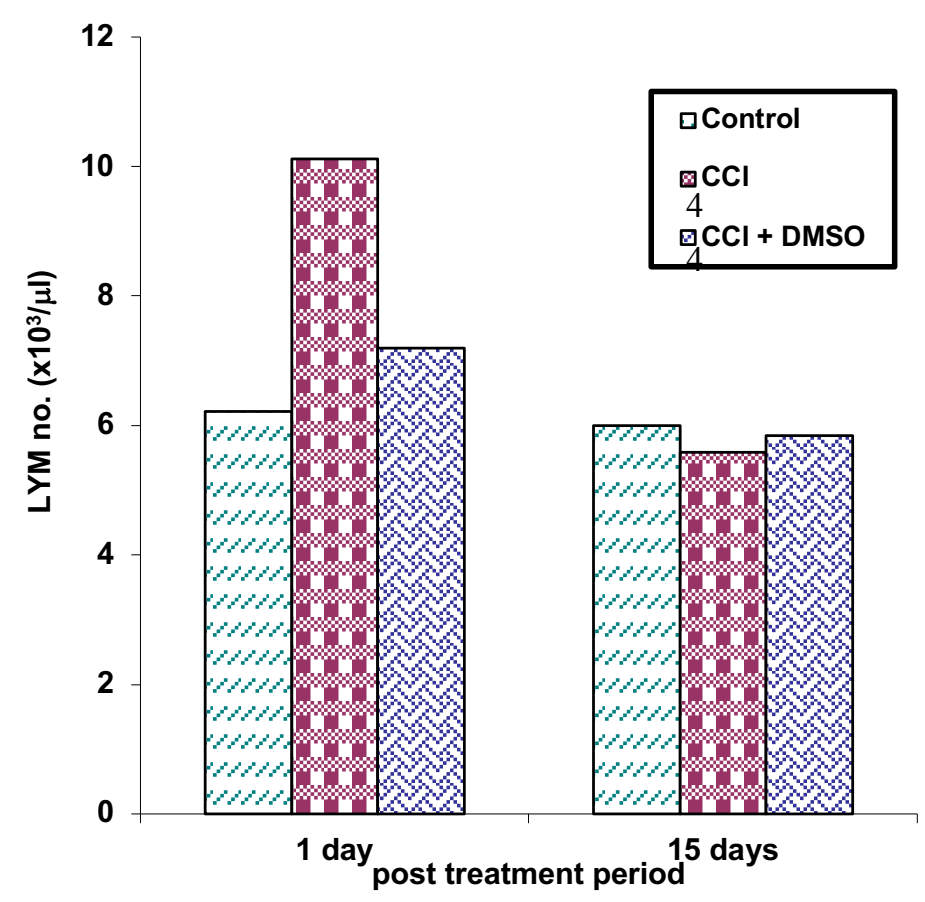

Fig(2): The effects of postoral administration of $\mathrm{CCl}_{4}(0.09 \mathrm{ml} / 100 \mathrm{~g}$ b.wt.) and that of DMSO (0.05 $\mathrm{ml} / 100 \mathrm{~g}$ b.wt.) administered intraperitoneally 30 minutes post each $\mathrm{CCl}_{4}$ administration every other day for one month on lymphocytes (LYM) number in male albino rats at the $1^{\text {st }}$ day and 15 days following termination of treatment period. . Each value represents the mean \pm SE of five separate experiments. 
Table (2): The effects of postoral administration of $\mathrm{CCl}_{4}(0.09 \mathrm{ml}$ $/ 100 \mathrm{~g}$ b.wt. $)$ and that of DMSO $(0.05 \mathrm{ml} / 100 \mathrm{~g} \mathrm{b.wt}$. $)$ administered intraperitoneally 30 minutes post each $\mathrm{CCl}_{4}$ administration every other day for one month on serum IgM concentration in male albino rats at the $1^{\text {st }}$ day and 15 days following termination of treatment period.

\begin{tabular}{|c|c|c|c|c|c|}
\hline $\begin{array}{c}\text { Measured } \\
\text { parameters }\end{array}$ & Treatment & $\begin{array}{c}\text { Post- } \\
\text { treatment } \\
\text { period }\end{array}$ & Control & Treated & $\begin{array}{c}\% \\
\text { difference }\end{array}$ \\
\hline \multirow{2}{*}{$\mathbf{I g M}$} & $\mathrm{CCL}_{4}$ & 1 day & $0.54 \pm 0.0457$ & $0.78 \pm 0.0560^{\mathrm{a}+}$ & 44.44 \\
\cline { 3 - 6 }$(\mathbf{g} / \mathbf{L})$ & \begin{tabular}{c}
$\mathrm{CCL} 4$ \\
+ \\
\cline { 3 - 6 }
\end{tabular} & 15 days & $0.56 \pm 0.0286$ & $0.72 \pm 0.0466^{\mathrm{a}+}$ & 28.57 \\
\cline { 2 - 6 } & DMSO day & $0.54 \pm 0.0457$ & $0.81 \pm 0.0567^{\mathrm{a}^{+}}$ & 50.00 \\
\hline
\end{tabular}

$\mathrm{a}+$ : Significant when compared with the control value where $\mathrm{P} \leq 0.05$ (t-test) 


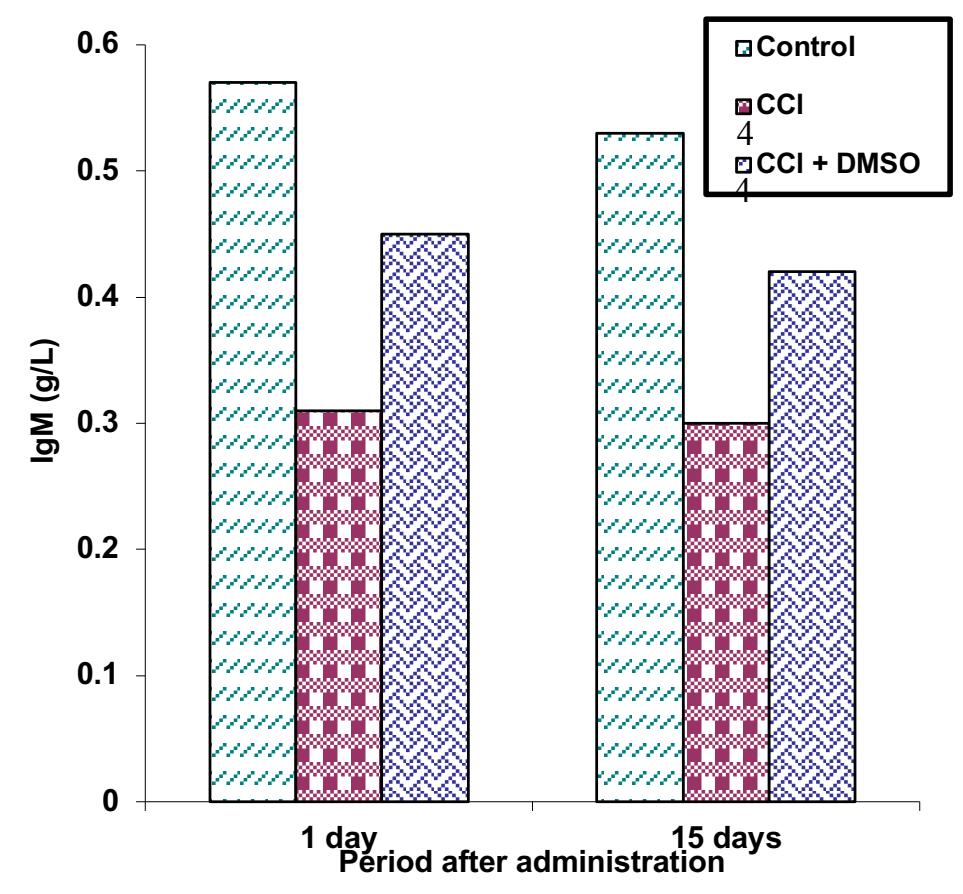

Fig(3): The effects of postoral administration of $\mathrm{CCl}_{4}(0.09 \mathrm{ml} / 100 \mathrm{~g}$ b.wt.) and that of DMSO (0.05 ml $/ 100 \mathrm{~g}$ b.wt.) administered intraperitoneally 30 minutes post each $\mathrm{CCl}_{4}$ administration every other day for one month on serum IgM concentration in male albino rats at the $1^{\text {st }}$ day and 15 days following termination of treatment period. Each value represents the mean $\pm \mathrm{SE}$ of five separate experiments. 
Table (3): The effects of postoral administration of $\mathrm{CCl}_{4}(0.09 \mathrm{ml}$ $/ 100 \mathrm{~g}$ b.wt. $)$ and that of DMSO $(0.05 \mathrm{ml} / 100 \mathrm{~g} \mathrm{b.wt}$. $)$ administered intraperitoneally 30 minutes post each $\mathrm{CCl}_{4}$ administration every other day for one month on serum IL-4 and IL-6 concentrations in male albino rats at the $1^{\text {st }}$ day and 15 days following termination of treatment period.

\begin{tabular}{|c|c|c|c|c|c|}
\hline $\begin{array}{c}\text { Measured } \\
\text { parameters }\end{array}$ & Treatment & $\begin{array}{c}\text { Post- } \\
\text { treatment } \\
\text { period } \\
\end{array}$ & Control & Treated & $\begin{array}{c}\% \\
\text { difference }\end{array}$ \\
\hline \multirow{4}{*}{ IL-4 (pg/ml) } & \multirow[t]{2}{*}{$\mathrm{CCl}_{4}$} & 1 day & $6.20 \pm 0.1445$ & $5.02 \pm 0.0048^{\mathrm{a}^{+}}$ & -19.03 \\
\hline & & 15 days & $6.20 \pm 0.1445$ & $5.09 \pm 0.1669^{a^{+}}$ & -17.90 \\
\hline & \multirow{2}{*}{$\begin{array}{c}\mathrm{CCl}_{4} \\
+ \\
\mathrm{DMSO}\end{array}$} & 1 day & $6.20 \pm 0.1445$ & $5.03 \pm 0.0588^{\mathrm{a}^{+}}$ & -18.87 \\
\hline & & 15 days & $6.20 \pm 0.1445$ & $4.99 \pm 0.0563^{\mathrm{a}-}$ & -19.52 \\
\hline \multirow{4}{*}{ IL-6 (pg/ml) } & \multirow[t]{2}{*}{$\mathrm{CCl}_{4}$} & 1 day & $9.62 \pm 0.1207$ & $8.70 \pm 0.1114^{\mathrm{a}+}$ & -9.60 \\
\hline & & 15 days & $9.62 \pm 0.1207$ & $9.06 \pm 0.1489^{a+}$ & -5.86 \\
\hline & \multirow{2}{*}{$\begin{array}{c}\mathrm{CCl}_{4} \\
+ \\
\mathrm{DMSO}\end{array}$} & 1 day & $9.62 \pm 0.1207$ & $8.97 \pm 0.2144^{\mathrm{a}+}$ & -6.72 \\
\hline & & 15 days & $9.62 \pm 0.1207$ & $8.77 \pm 0.0773^{a^{+}}$ & -8.88 \\
\hline
\end{tabular}

$\mathrm{a}+$ : Significant when compared with the control value where $\mathrm{P} \leq 0.05$ (t-test)

a- : Non significant when compared with the control value where $\mathrm{P} \leq 0.05$ (t-test) 


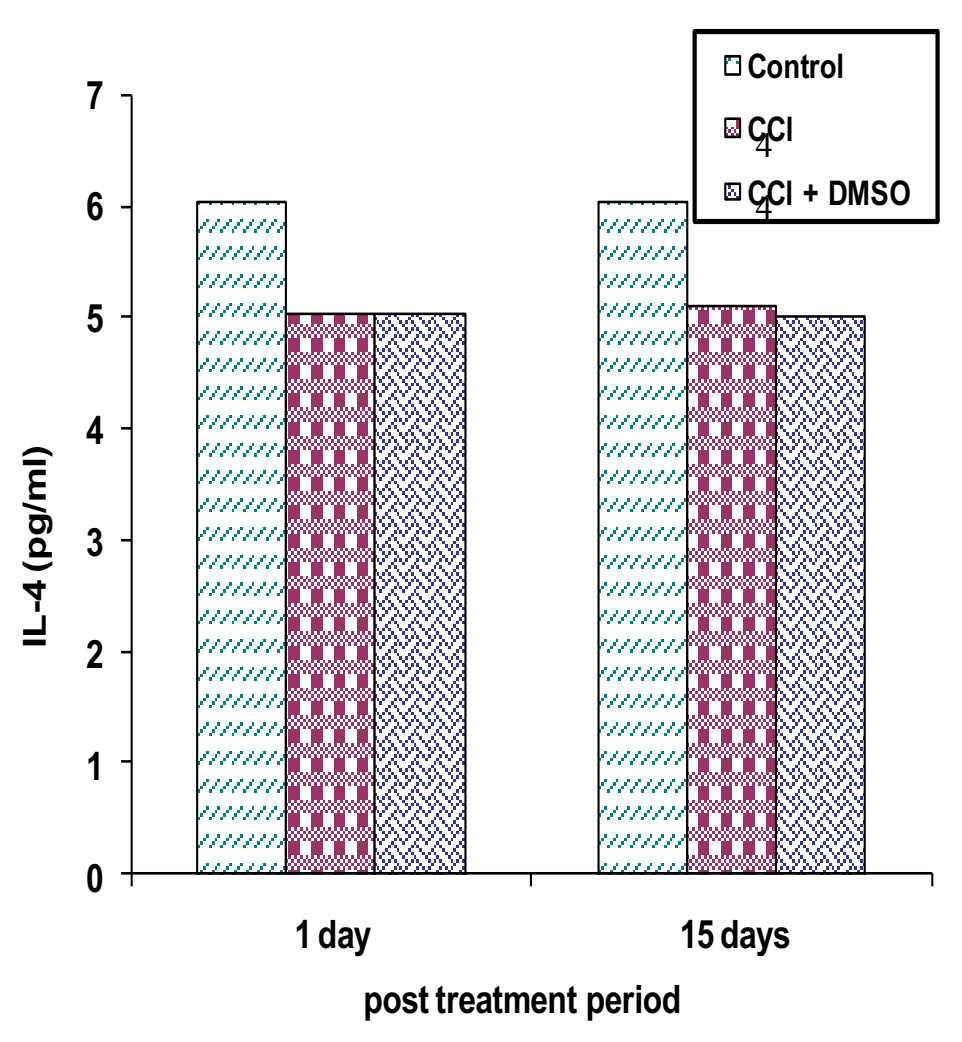

Fig(4): The effects of postoral administration of $\mathrm{CCl}_{4}(0.09 \mathrm{ml} / 100 \mathrm{~g}$ b.wt.) and that of DMSO (0.05 $\mathrm{ml} / 100 \mathrm{~g}$ b.wt.) administered intraperitoneally 30 minutes post each $\mathrm{CCl}_{4}$ administration every other day for one month on serum IL-4 concentration in male albino rats at the $1^{\text {st }}$ day and 15 days following termination of treatment period. Each value represents the mean $\pm S E$ of five separate experiments. 


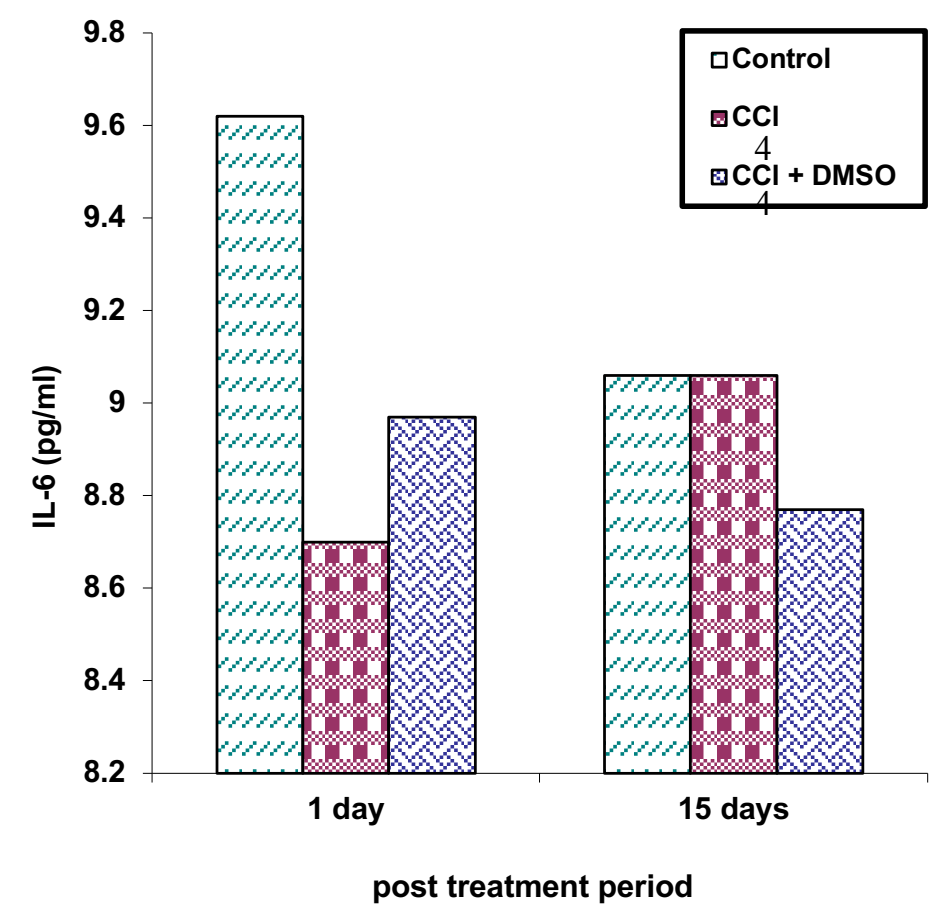

Fig(5): The effects of postoral administration of $\mathrm{CCl}_{4}(0.09 \mathrm{ml} / 100 \mathrm{~g}$ b.wt.) and that of DMSO (0.05 $\mathrm{ml} / 100 \mathrm{~g}$ b.wt.) administered intraperitoneally 30 minutes post each $\mathrm{CCl}_{4}$ administration every other day for one month on serum IL-6 concentration in male albino rats at the $1^{\text {st }}$ day and 15 days following termination of treatment period. Each value represents the mean \pm SE of five separate experiments. 


\section{DISCUSSION}

The organic solvent and environmental contaminant $\mathrm{CCl}_{4}$ (ATSDR, 2003), has been identified as an immunotoxicant (Jeon $\boldsymbol{e t}$ al., 1997; Ladics et al., 1998) in addition to its hepatotoxic, nephrotoxic and a probable carcinogenic effects (Sundori et al., 1997; Thrall et al., 2000; Ogeturk et al., 2005a,b).

The results obtained in the present investigation indicate that postoral (po) administration every other day for one month of $\mathrm{CCl}_{4}$ at a dose of 1/10 LD $50,0.09 \mathrm{ml} / 100 \mathrm{~g}$ b.wt. caused significant increases in total leucocytes (WBCs), lymphocytes (LYM) count and serum immunoglobulin IgM at the first day following the treatment period. These changes were reversed in case of WBCs and LYM but decreased in case of IgM at day 15 post termination of $\mathrm{CCl}_{4}$ treatment period. Farombi et al. (1997) have observed significant decrease in total WBCs number in male Wister rats as a result of oral $\mathrm{CCl}_{4}(0.5$ $\mathrm{ml} / \mathrm{kg}$ b.wt) administration. Causes of leucopenia have been reported to be the depression of the blood forming elements and/or destruction and degeneration of these cells as a result of chemical agents (Tirkey et al., 2005). Therefore, the present simultaneous increase in WBCs and LYM could be speculated to be a result of $\mathrm{CCl}_{4}$-induced activation of the haematopoiesis process in the bone marrow.

In previous study on male CD rats, oral administration of 12.5 and $25 \mathrm{mg} / \mathrm{kg}$ b.wt. $\mathrm{CCl}_{4}$ for 30 days decreased sRBC-specific serum IgM level, while administration of $25 \mathrm{mg} / \mathrm{kg}$ b.wt $\mathrm{CCl}_{4}$ for 90 days increased sRBC specific IgM level (Ladics et al., 1998). Delaney $\boldsymbol{e t}$ $\boldsymbol{a l} \mathbf{~}^{(9)}$ found that $\mathrm{CCl}_{4}$-induced suppression of the humoral immune response to the T-cell dependent antigen sRBC was due to the induction of a serum-borne immunosuppressive factor, i.e transforming growth factor- $\beta 1$ (TGF- $\beta 1$ ) by $\mathrm{CCl}_{4}$. In contrast to the finding of Ladics and co-workers ${ }^{(11)}$, Smialowicz et al ${ }^{(36)}$ reported that exposure of Fisher 344 rats to $5-40 \mathrm{mg} / \mathrm{kg}$ b.wt $\mathrm{CCl}_{4}$ for 10 days did not alter the primary humoral immune response to sRBC. Differences in the effect of $\mathrm{CCl}_{4}$ have been suggested to be attributed to the use of different rat strains (Ladics et al., 1998).

In the present study, it has been observed that repeated po administration of $\mathrm{CCl}_{4}$ into male rats every other day for 30 days 
induced significant increases in serum IL-4 and IL-6 levels that were lasted for 15 days post administration. A possible indirect role of TGF- $\beta 1$ in that long lasting decrease of IL- 4 is supported by previous observation that direct addition of TGF- $\beta 1$ to naïve splenocytes culture produced marked and dose-related inhibition of the anti-sRBC IgM antibody forming cell response coincided with a decrease in Thelper cytokine IL-4 (Jeon et al., 1997).

It has been reported that IL- 6 production is induced by many proinflammatory factors such as IL-1 and tumor necrosis factor (TNF$\alpha)$ cytokines, histamine, and prostaglandin $\mathrm{E}_{2}\left(\mathrm{PGE}_{2}\right)$ in various cells (Barton, 1996). These inflammatory cytokines were detected in the peritoneal cavity of rats immediately after ip $\mathrm{CCl}_{4}$ administration and that they increase IL-6 production in culture mesothelial cells (Yamaji et al., 2008). This IL-6 production process could explain the high level of IL-6 production which peaked at $4 \mathrm{hr}$ in the peritoneal cavities of rat administered $\mathrm{CCl}_{4}$ intraperitoneally (Zuinen et al., 2007).

A possible inhibition of these proinflammatory production could be speculated as a cause of the decrease in IL- 6 concentration recorded in the present investigation.

The present study demonstrated that i.p. administration of DMSO $\left(0.5 \mathrm{ml} / 100 \mathrm{~g}\right.$ b.wt.) 30 minutes following each po $\mathrm{CCl}_{4}$ treatment to rats succeeded in preventing selectively the toxic effects on total WBCs and LYM numbers recorded at one day after $\mathrm{CCl}_{4}$ treatment period, but has no effect on changes in serum IgM, IL-4 and IL-6 induced by $\mathrm{CCl}_{4}$ administration. It has been previously reported that in the chemically induced liver injury or kidney damage, DMSO was administered prior to or concomitant with the toxicants (Lind \& Gandolfi, 1997; 1999; Bruck et al., 1999).

The protective action of DMSO when administered prior to or concomitant with the toxicants has been attributed to DMSO-induced inhibition of bio-activation of the compounds to toxic intermediates (Lin \& Gandolfic, 1997). In evaluating a number of known hepatoprotective agents for their late (hours after toxicant exposure) protective effects, it was found that DMSO was a highly efficacious protective agent (Lind et al., 1990, 1992, 1994). The potential 
mechanisms of the protective action of late administration of DMSO in the guinea pig model of halothane hepatotoxicity were investigated by observing its effect on halothane biotransformation, covalent binding by reactive intermediates to liver protein, and hepatic glutathione (GSH) concentration (Lind et al., 1997). They compared their results with those obtained with the structurally analogous cytochrome P-450 2E1 CYPeE1) inhibitor diallyl sulfide. DAS, which provided evidence for mechanism of late DMSO protection being unlike and not due to inhibition of biotransformation. In more recent study, Kishioka et al. ${ }^{(31)}$ reported that the necrosis of the liver induced by the hepatotoxin thioacetamide in rats was totally prevented by coadministration of DMSO 18 and $1 \mathrm{~h}$ before and $8 \mathrm{~h}$ after each administration of thioacetamide. They suggested that the protective effect of DMSO was related to its antioxidative property.

\section{REFERENCES}

1. Agency for Toxic Substances and Disease Registry, ATSDR (2003): Toxicological profile for carbon tetrachloride. US Department of Health and Human Services. Public Health Service: Atlanta, GA..

2. Doherty, R.E. (2000): A history of the production and use of carbon tetrachloride, carbon tetrachloroethylene, trichloroethylene and 1,1,1-trichloroethane in the United States: Part 1-Historical background; Carbon tetrachloride and tetrachloroethylene. Environmental Forensics 1 (1): 69-81.

3. Sundori, P.N.; Wilfred, G. and Ramakrishna, B. (1997): Does oxidative protein damage plays a role in the pathogenesis of carbon tetrachloride-induced liver injury in the rat? Biochem. Biophys Acta, 1362: 169-176.

4. Ogeturk, M.; Kus, I.; Colakoglu, N.; Zararsiz, I.; Ilhan, N. and Sarsilmaz, M. (2005): Caffeic acid phenethyl ester protects kidneys against carbon tetrachloride toxicity in rats. Journal of Ethnopharmacology, 97: 273 - 280. 
5. Ogeturk, M.; Kus, I.; Kavakli, A.; Oner, J.; Kukner, A. and Sarsilmaz, M. (2005): Reduction of carbon tetrachlorideinduced nephropathy by melatonin administration, 23: 85-92.

6. Thrall, K.D.; Vucelick, M.E.; Gies, R.A.; Zangar, R.C.; Weitz, K.K.; Poet, T.S.; SPrnger, D.L.; Grnat, D.M. and Benson, J.M. (2000): Comparative metabolism of carbon tetrachloride in rats, mice and hamsters using gas uptake and PBPK modeling. J. Toxicol. Environ. Health A., 60: 531-548.

7. Kaminski, N.E.; Jordan, S.D. and Holsapple, M.P. (1989): Suppression of humoral and cell-mediated immune responses by carbon tetrachloride. Toxicological Science, 12(1): 117-128.

8. Kaminski, N.E.; Barnes, D.W.; Jordan, S.D. and Holsapple, M.P. (1990): The role of metabolism in carbon tetrachloridemediated immunosuppression: In vivo studies. Toxicology and Applied Pharmacology, 102(1): 9-20.

9. Delaney, B.; Strom, S.C.; Collins, S. and Kaminski, N.E. (1994): Carbon tetrachloride suppresses T-cell-dependent immune responses by induction of transforming growth factor- $\beta 1$. Toxicology and applied Phammacology, 126(1): 98-107.

10. Jeon, Y.J.; Han, S.H.; Yang, K.H. and Kaminsk, N.E. (1997): Induction of liver-associated transforming growth factor $\beta 1$ (TGF- $\beta 1$ ) mRNA expression by carbon tetrachloride leads to the inhibition of $T$ helper 2 cell-associated lymphokines. Toxicology and Applied Pharmacology, 144(1): 27-35.

11. Ladics, G.S.; Smith, C.; Elliott, G.S.; Slone, T.W. and Loveless, S.E. (1998): Further evaluation of the incorporation of an immunotoxicological functional assay for assessing humoral immunity for hazard identification purposes in rats in a standard toxicology study. Toxicology, 126(2): 137-152. 
12. Merino, N.; Gonzalez, R.; Gonzalez, A. and Remirez, D. (1996): Histopathological evaluation on the effect of red propolis on liver damage induced by $\mathrm{CCl} 4$ in rats. Archives of Med. Res., 27: 285-28.

13. Bahceciogla, I.H.; Ustundag, B.; Ozercan, I., Ercel, E.; Baydas, G.; Akdere, T. and Demir, A. (1999): Protective effect of Ginkgo biloba extract on $\mathrm{CCl}_{4}$-induced liver damage. Hepatology Research, 15: 215-224.

14. Donder, E.; Baydas, G.; Ozkan, Y.; Ercel, E.; Yalniz, M. and Dogan, H. (1999): Investigation of antioxidant effect of melatonin against carbon tetrachloride toxicity in various tissues. Biomed. Res., 10: 141-145.

15. Fadhel, Z.A. and Amran, S. (2002): Effects of black tea extract on carbon tetrachloride-induced lipid peroxidation in liver, kidneys, and testes of rats. Phytotherapy Res. 16: 28-.32.

16. Goodman, J.W. (1991): Immunoglobulin structure \& function. In: Basic and Clinical Immunology. 7th ed. Stites, D.F. and Terr, A.T. Eds. Appleton \& Lange, Norwalk, Connecticut/San Mateo, California.

17. Goldsby, R.A.; Kindt, T.J.; Osborne, B.A. and Kuby, J. (2003): Immunology 5th ed. Chap. 4. W.H. Freeman and Company, New York.

18. Dinarello, C. A. (2007): Historical insights into cytokines. Eur. J.Immunol., 37(Suppl. 1): S34-S45.

19. Noelle, R.; Krammer, P.H.; Ohara, J.; Uhr, J.W. and Vitetta, E.S. (1984): Increased expression of Ia antigens on resting B-cells: an additional role for B-cell growth factor. Proc. Nat]. Acad. Sci. USA, 81: 6149.

20. Roehm, N.W.; Leibson, H.J.; Zlotnick, A.; Kappler, J.; Marrack, P. and Cambier, J.C. (1984): Interleukin induced increase in Ia expression by normal mouse $B$ cells. J. Exp. Med., 160: 679. 
21. DeFrance, T., Aubry, J.P., Rousset, F., Vanbervliet, B.,Bonnefoy, J.Y., deVries, J. and Banchereau, J. (1987):Human interleukin4 induces Fc, receptors (CD 23) onnormal human B lymphocytes. J. Exp. Med. 165, 1459

22. Barton, B.E. (1996): The biological effects of interleukin-6. Med. Res. Rev., 16: 87-109.

23. Biffl, W. L.; Moore, E. E.; Moore, F. A. and V. M. Peterson. (1996): Interleukin-6 in the injured patient. Marker of injury or mediator of inflammation? Ann. Surg., 224: 647-664.

24. Van der Boll, T., and van Deventer, S. J. (1998): The role of interleukin-6 in endotoxin-induced inflammatory responses. Prog. Clin. Biol. Res., 397: 365-377.

25. Basile, A.S.; Huang, J.M.; Xie, C.; Webster, D.; Berlin, C. and Skolnick, P. (1996): N-methyl-D-aspartate antagonists limit aminoglycoside antibiotic-induced hearing loss. Nat. Med., 2: 1338-1343.

26.Szonyi, M.; He, D.Z.; Ribari, O.; Sziklai, I. and Dallos, P. (2001): Intracellular calcium and outer hair cell electromotility. Brain Res., 922: 65-70

27. Harris, K.C.; Hu, B.; Hangauer, D. and Henderson, D. (2005): Prevention of noise-induced hearing loss with Src-PTK inhibitors. Hears. Res., 208: 14-25.

28. Lind, R.C. and Gandolfi, A.J. (1997): Late dimethyl sulfoxide administration provides a protective action against chemically induced injury in both the liver and the kidney. Toxicol. Appl. Pharmacol., 142: 201-207.

29. Lind, R.C. and Gandolfi, A.J. (1999): Hepatoprotection by dimethyl sulfoxide. I. Protection when given twenty-four hours after chloroform or bromobenzen. Toxicol. Pathol., 27: 342-347. 
30. Gilot, D.; Loyer, P.; Corlu, A.; Glaise, D.; Lagadic-Gossmann, D.; Atfi, A.; Morel, F.; Ichijo, H. and Guguen-Guillouzo, C. (2002): Liver protection from apoptosis requires both blockage of initiator caspase activities and inhibition of ASK1/JNK pathway via glutathione S-transferase regulation. J. Biol. Chem., 277: 49220-49229.

31. Kishioka, T.; Lida, C.; Fuji, K.; Nagae, R.; Onishi, Y.; Ichi, I. and Kojo, S. (2007): Effect of dimethyl sulphoxide on oxidative stress, activation of mitogen activated protein kinase and necrosis caused by thioacetamide in the rat liver. Eur. J. Pharmacol., 564: 190-195.

32. Reed, L.H. and Meuench, H. (1938): A simple method of estimating fifty percent point. Am. J. Hyg. 37: 493.

33. Brown, B.A. (1993) : Haematology principles and procedures. 6th ed . Lippincot, Williams \& Wilking . Philadelphia .

34. Farombi, E.O.; Nwankwo, J.O. and Emerole, G.O. (1997): Possible modulatory effect of browned yam flour diet on chemically-induced toxicity in the rat-food and chemical. Toxicology, 35: 10-11, 975-979.

35. Trikey, N.; Pilkhwal, S.; Kuhad, A. and Chopra, K. (2005): Hesperidin, a citrus bioflavonoid, decreases the oxidative stress produced by carbon tetrachloride in rat liver and kidney. BMC Pharmacology, 5: 2-9.

36. Smialowicz, R.J.; Simmons, J.E.; Luebke, R.W. and Allis, J.W. (1991): Immunotoxicologic assessment of subacute exposure of rats to carbon tetrachloride with comparison to hepatotoxicity and nephrotoxicity. Fundamental and Applied Toxicology, 17(1): 186-196.

37. Yamaji, K.; Ohnishi, K.; Zuinen, R.; Ochiai, Y.; Chikuma, T. and Hojo, H. (2008): Interleukin - 6 production by peritoneal mesothelial cells and its regulation by inflammatory factors in rats administered carbon 
tetrachloride intraperitoneally. Toxicology and Applied pharmacology, 226: 38-45.

38. Zuinene, R.; Yamaji, K.; Aoki, M.; Chikuma, T. and Hojo, H. (2007): Early induced, high-level interleukin-6 expression in the rat peritoneal cavity into which a hepatotoxicant carbon tetrachloride was administered. Toxicology Letters, 170: 42 - 48.

39. Bruk, R.; Aeed, H.; Shirin, H.; Matas, Z.; Zaidel, L.; Avni, Y. and Helper, Z. (1999): The hydroxyl radical scavengers dimethyl sulfoxide and dimethylthiourea protect rats against thioacelamide induced fulminant hepatic failure. J. Hepatol., 31: $27-38$.

40. Lind, R. C.; Gandolfi, A. J. and Hall, P. de la M. (1990): Covalent binding of oxidative biotransformation intermediates is associated with halothane hepatotoxicity in guinea pigs. Anesthesiology, 73, 1208-1213

41. Lind, R. C.; Gandolfi, A. J. and Hall, P. de la M. (1992): Glutathione depletion enhances subanesthetic halothane hepatotoxicity in guinea pigs. Anesthesiology, 77, 721-727.

42. Lind, R. C.; Gandolfi, A. J. and Hall, P. de la M. (1994): A model for fatal halothane hepatitis in the guinea pig. Anesthesiology, 81, 478-487.

43. Lind, R.C.; Gandolfi, A.J.; Brown, B.R. and Hall, P. de la M. (1997): Halothane hepatotoxicity in guinea pigs. Anesth. Analg., 66: 222-228. 